\title{
TRIANGULATION AS A POWERFUL METHODOLOGICAL RESEARCH TECHNIQUE IN TECHNOLOGY-BASED SERVICES
}

Mohammed ASHOUR ${ }^{1}$

\author{
Received Date (Başvuru Tarihi): 29/01/2018 \\ Accepted Date (Kabul Tarihi): 19/03/2018 \\ Published Date (Yayın Tarihi): 20/04/2018
}

\begin{abstract}
This research is an attempt to idntfiy triangulation techniques that helps in overcoming constraints facing researchers within service markets based on high technology. Because of the high contact customertelecommunication services providers (TSP) relationship, its reliability on the advanced rapid technology, and its short life cycle, telecommunication services are classified as a highly complex services market. In addition to the predominant characteristics of service, TSPs` marketing activities are directed at people (not goods), a matter that causes considerable difficulties in conducting research in telecommunication markets and also cusses challenges regarding finding acceptance. Hence, the pluralist perspective of triangulation, gives more attention on matching between various methodological techniques and difficulties in researching in such complicated markets. Moreover, triangulation as a methodological approach provides alternative techniques that may enable overcoming bias, eclecticism or other researching problematic issues. The purpose of this article is to explore the difficulties that pose a threat with respect to the validity and credibility of research output within high-tech services and the appropriate methodological research techniques the researcher can utilize to overcome these obstacles.
\end{abstract}

Keywords: Triangulation, Tech-Based Services, Telecommunication Services Complexities, Jordan. JEL Codes: B49, C18

\section{GÜÇLÜ BİR METODOLOJIK ARAŞTIRMA YÖNTEMİ OLARAK ÇEŞiTLEME}

\section{ÖZ}

Bu araştırma, yüksek teknoloji hizmeti sunan sektörlerde araştırmacıların karşılaştıkları problemlerin üstesinden gelmede, çeşitleme yöntemlerinin uygunluğunun önemini vurgulamayı amaçlar. Müşteritelekomünikasyon hizmet să̆layıcıları (THS) arasındaki iletişimin sıklı̆̆g, gelişmiş hızlı teknolojinin güvenirliğ ve kısa sürmesi nedeniyle, telekomünikasyon hizmetleri oldukça karmaşık bir hizmet sektörü olarak tanımlanmaktadır. Hizmetin öne çıkan bu özelliklerine ek olarak, THS'lerin pazarlama faaliyetlerinin (mallara değil) insanlara yönelik olması da, telekomünikasyon sektöründe araştırmalar yapma konusunda büyük sıkıntılara yol açmakta ve kabul görme konusunda güçlükleri beraberinde getirmektedir. Bu nedenle, çeşitlemenin çoğulcu bakış açısı, çeşitli metodolojik yöntemler arasındaki uyuma ve bu türden karmaşık sektörlerde araştırma yapma zorluklarına daha dikkatli bir biçimde yaklaşmaktadır. Ayrıca, metodolojik bir yaklaşım olarak çeşitleme, önyargı, eklektizm veya diğer problemli meselelerin aşılmasını sağlayacak bir alternatif teknik sunmaktadır. Bu çalışmanın amacı yüksek teknolojili hizmetler içerisindeki araştırma çıktılarının güvenilirliği ve geçerliliğine tehdit oluşturan güçlükleri ve bu güçlüklerin aşılmasında araştırmacının yararlanabileceği uygun metodolojik araştırma tekniklerini incelemektir.

Anahtar Kelimeler: Çeşitleme, Teknoloji Tabanlı Hizmetler, Telekomünikasyon Hizmetleri Güçlükleri, Ürdün JEL Kodları: B49, C18

\footnotetext{
${ }^{1}$ Assitant Professor, Al Zaytoonah Uneversity of Jordan, m.ashour@zuj.edu.jo
} 


\section{INTRODUCTION}

Triangulation as a methodological research technique is supposed to support both: the validation and the competences of research findings (Gibson, 2017: Ammenwerth, et al., 2003), in such a complex environment. As a preferred methodological strategy in services (Gilmore and Carson, 1996), through triangulation not only validation is aimed at but "deepening and widening" researcher`s understanding about the studied phenomenon too, as Olsen (2004) stated.

Triangulation as a methodological technique refers to the use of multi-method approach in which different investigative methods are applied to the same phenomenon (Burton, et al., 2017: Kern, 2016: Erzberger and Prein, 1997) in order to pinpoint the phenomenon, to improve the accuracy of the observations (Mason, 2006) and to facilitate validation of collected data (Bogdan and Biklen, 2006).

Triangulation through using a multi-method approach in investigating a phenomenon, aims to achieve two major objectives as (Ammenwerth, et al., 2003, p.3) explained "Validation: to support a finding with the help of the others and completeness: to complement the data with new results, thus to find new information, to get additional pieces to the overall puzzle".

The term triangulation derives from navigating in which several points are used for determining of a ship's or aircraft's position (Ammenwerth, et al., 2003). While triangulation is a common technical term in telecommunications markets for locating the geographic position of a service user, Bryman (n.d.) notes that the term is drawn from surveying where a set of triangles are used to map out an area.

In social research an early application to triangulation related to the Campbell and Fiske "multitrait-multi method matrix" work in 1959 in which - within a mathematical model - they stressed "employing several methods simultaneously" in order to assess all aspects of the phenomenon as Mathison (1988) stated.

Thus, triangulation in evaluation is a methodological powerful technique (Holtzhausen, 2000; Bogdan and Biklen, 2006) that facilitates validation of data through using a combination of several research methodologies (sources of data, evaluators, methods, or theories) in the study of the same phenomenon. 


\section{METHODOLOGY}

Although related literature classified research according to perception of the world into several different philosophies (e.g. realism, positivism, pragmatism, etc) qualitative and quantitative are seen as two major approaches in which research could be classified. Qualitative research is an umbrella term covering an array of interpretative techniques that help us understand and explain the meaning of social phenomena, otherwise come to terms with the meaning, not the frequency, of certain more or less naturally occurring phenomena in the social world (Van Manen, 1990 cited in Al-Busaidi, 2008, p.11).

This research adopts the systematic reviews as appropriate research technique intending to provide a complete, exhaustive summary of current literature relevant to a research question. According to Kitchenham (2004) such type of research approach is not only limited to primary sources of data, it involves the collection, analysis and interpretation of data, although the data derive from secondary sources represented in reviewing other research.

Although systematic reviews are increasingly being used as a preferred research method in medicine and health care (Bettany-Saltikov, 2012; Sambunjak \& Puljak, 2010) however, they are not limited to these research domains and are quite common in all other sciences where data are collected, published in the literature would be helpful (Ader et al., 2008).

In addition, this paper goes beyond the narrative review of the literature of research methodology to assess the role of triangulation strategies (e.g. data, strategies, theoretical) in improving the reliability and validity of research techniques adopted by researchers in volatile environments such as the tech-based service markets that are changing radically due to the combination of globalisation, market forces and innovative technologies. Several variables contributed to the adoption of the present research methodology. The nature of research purpose, and research domain are seen as key aspects determined the research design.

Boaz and Sidford (2006) argued that, the good systematic review guides promote the development of a precisely defined review question in the hope that this will lead to a more focused review. Consequently, this research followed the five key steps indicated by Boaz and Sidford (2006) as substantial steps in reviewing process as shown in Figure 2 below. 


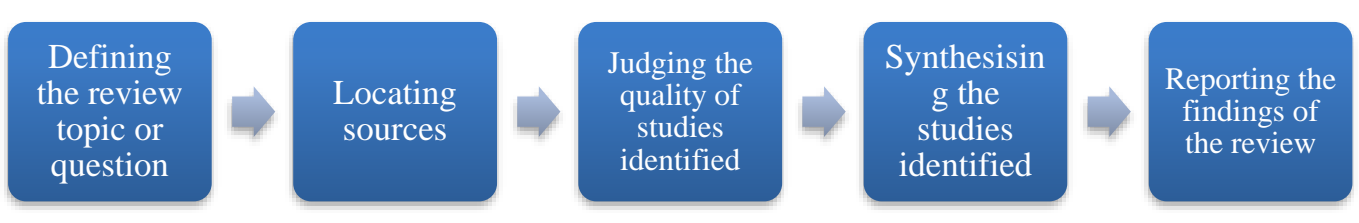

*Adapted from Boaz and Sidford (2006)

Figure1: Key Steps in Litrature Review

To summarize, because of the need to concentrate on meanings, not facts, and the attention given to understanding what is happening, this research positions itself within the qualitative perspective.

\section{JUSTIFICATION FOR TRIANGULATION}

Volatile situations, unique services characteristics, firm customer interaction, nature of demand and reluctance to disclose information may allow eclecticism, skepticism which is reflected negatively in the credibility and persuasiveness in research findings carried out in services. Triangulation advocates (Denzin, 1978; Miles and Huberman, 1994; Perlesz, and Lindsay, 2003; Bryman, et al., 2008) argue that, through the combining of multiple methods, measures and theories, triangulation allow circumventing the predominant constraints of services. Initially, researchers who use two or more data resources will achieve more rational outcomes than who use of a single source. This is the basic notion of triangulation.

The high-tech services market is characterized from other markets by the mutual relations, unique service determinants, deregulation and stiff competition, in addition to the challenges posed by the consequences of the acceleration of technology. All were reflected in the multiplicity of themes and aspects that have to be taken into account when evaluating phenomenon in the market.

Therefore, to carry out a study with the omission of important aspects in this market will result in increasing the likelihood of potential neglected areas, which is seen as eclecticism and weakness in the validity of search findings. Mathison (1988, p. 17) emphasized that: "Practicing researchers and evaluators know that the image of data converging upon a single proposition about a social phenomenon is a phantom image ${ }^{\text {. }}$

But to the contrary, in the execution of a phenomenon evaluating, triangulation as a pluralist approach, focus is on a synergistic combination of using multiple methodological 
approaches which enable and facilitate validation of data through corroboration with each other. "Phenomenon is 'measured' from two or more different vantage points, in order to pinpoint the phenomenon, or to improve, test or validate the accuracy of the observation “ (Mason, J. 2006, p. 8) which will result in "different images of understanding" as Smith and Kleine (1986) suggested in Mathison (1988, p. 2) thus increasing the "potency" of evaluation findings. Here too, when multiple data, theories or investigations are complementarily employed in order to interpret a particular social phenomenon, validity will be increased, and elimination of bias will be reinforced. Unambiguously, triangulation aims to achieve a meaningful image, complete description and holistic understanding for the phenomenon.

\section{TYPES OF TRIANGULATION}

A distinct body of related literature has discussed the different alternatives for the dyadic employment of both: qualitative and quantitative methods. Purposes, advantages or limits were focused on through using the mixed or the integrated approach. Triangulation as a methodological technique is more comprehensive and beyond the qualitative-quantitative applications as a research method.

For achieving a "balanced picture of the situation" (Altrichter, et al., 2008), triangulation draws on using a combination of several research options. Methods, theories, sources of data and multiple numbers of researchers, are all potential methodological alternatives techniques in the same phenomenon. Following the discussion on triangulation applications, while Denzin (1978) suggested four different types, Guion (2002) stressed the environmental factor as the fifth type of triangulations:

a. Data triangulation: involves time, space, and persons.

b. Investigator triangulation: involves multiple researchers in an investigation.

c. Theory triangulation: involves using more than one theoretical position in the interpretation of the phenomenon.

d. Methodological triangulation: involves using of more than one method for gathering data (interviews, questionnaires, documents, etc.).

e. Environmental triangulation: involves the use of different locations, settings and other key factors related to the environment in which the study took place, such as time of the day, day of the week or season of the year. 
Table1: Research Challenges within Tech-Based Services

(The Case of Telecommunication Services sector in Jordan)

\begin{tabular}{|c|c|c|}
\hline $\begin{array}{c}\text { Telecommunication } \\
\text { Services } \\
\text { Analysis Level }\end{array}$ & Categories & $\begin{array}{c}\text { Potential Research } \\
\text { Complexities }\end{array}$ \\
\hline $\begin{array}{c}\text { Nature of } \\
\text { Telecommunication } \\
\text { Services Providers } \\
\text { (TSPs) }\end{array}$ & $\begin{array}{l}\text { Purpose: } \\
\text { - Satisfying customers` needs } \\
\text { related to telecommunication } \\
\text { services. (Both: individual } \\
\text { and business) } \\
\text { Structure: } \\
\text { - Large companies with } \\
\text { expensive infrastructures. } \\
\text { - International alliances } \\
\text { Type: } \\
\text { - Private sectors }\end{array}$ & $\begin{array}{l}\text { - Difficulties in identifying customer satisfaction } \\
\text { measurement criteria. } \\
\text { - Eclecticism: caused by researcher`s applied } \\
\text { methods in choosing participants, data resources or } \\
\text { preferred answers. } \\
\text { - Language inaccuracies: due to the common use for } \\
\text { the technical or telecommunication terms. } \\
\text { - Difficulties in obtaining the acceptance to } \\
\text { participate in research. }\end{array}$ \\
\hline $\begin{array}{c}\text { Competition } \\
\text { and } \\
\text { Environmental Factors }\end{array}$ & $\begin{array}{l}\text { Industry structure: } \\
\text { - Limited number of TSPs } \\
\text { within highly competitive } \\
\text { market. } \\
\text { Markets and legal } \\
\text { environment: } \\
\text { - Open markets deregulation } \\
\text { and privatization polices. } \\
\text { Technology: } \\
\text { - Based on turbulent } \\
\text { technology environment. } \\
\text { - Short life cycle services } \\
\text { depend on the rapid } \\
\text { technological innovations. }\end{array}$ & $\begin{array}{l}\text { - Risks related the weakness of results generalization. } \\
\text { (Because of the limited number of firms that may } \\
\text { accept to participate in research ) } \\
\text { - Reticence and lack of disclosure related sensitive } \\
\text { information caused by competition in addition to } \\
\text { inaccuracies or lack of data because of awareness of } \\
\text { competitors' intelligence activities. } \\
\text { - The affects of regional or international markets } \\
\text { factors. } \\
\text { - Evaluating the rapidly evolving of customer } \\
\text { preferences and needs related to short life cycle } \\
\text { services. }\end{array}$ \\
\hline $\begin{array}{l}\text { TSP-Customer } \\
\text { Relationship }\end{array}$ & $\begin{array}{l}\text { Type of relationship: } \\
\text { - Membership: subscribers } \\
\text { Degree of participation: } \\
\text { - Customer should be in } \\
\text { contact with his TSP during } \\
\text { receiving telecommunication } \\
\text { service. }\end{array}$ & $\begin{array}{l}\text { - Evaluating TSP-Customer relationship requires } \\
\text { considering many complex behavioural } \\
\text { (psychological and social) aspects. } \\
\text { - The potential objectivism problematic, in case of } \\
\text { researcher`s engaged influenced the studied issues. } \\
\text { - Customer's judgment on the quality of provided } \\
\text { services is influenced by internal and external } \\
\text { circumstances during receiving telecommu-nication } \\
\text { service. }\end{array}$ \\
\hline
\end{tabular}




\begin{tabular}{|c|c|c|}
\hline $\begin{array}{l}\text { Telecommunication } \\
\text { Services } \\
\text { Analysis Level }\end{array}$ & Categories & $\begin{array}{c}\text { Potential Research } \\
\text { Complexities }\end{array}$ \\
\hline $\begin{array}{c}\text { Service Nature of } \\
\text { Telecommunication } \\
\text { Service }\end{array}$ & $\begin{array}{l}\text { Degree of tradability: } \\
\text { - Pure telecommunication } \\
\text { services. } \\
\text { - Other complementary services } \\
\text { and goods. } \\
\text { Services directed toward: } \\
\text { - Individuals } \\
\text { Degree of merchantability: } \\
\text { (The degree to which } \\
\text { telecommunication service } \\
\text { works correctly and is suitable } \\
\text { for someone to purchase and } \\
\text { use without serious risk). }\end{array}$ & $\begin{array}{l}\text { - Difficulties in evaluating the performance of the } \\
\text { core telecom service because of the overlapping of } \\
\text { core and complementary services. } \\
\text { (could not to be isolated easily from } \\
\text { complementary services) } \\
\text { - Reticence and lack of disclosure because of personal } \\
\text { or financial considerations. } \\
\text { - Difficulties related the large size of samples in such } \\
\text { research. } \\
\text { (In case of customer behaviour researches because } \\
\text { of the nature of telecommunication services which } \\
\text { is directed almost to all segments or all peoples ) } \\
\text { - Difficulties in evaluating customer perceptions risk } \\
\text { and service quality related to inseparability. } \\
\text { - The potential objectivism problematic, in case of } \\
\text { researcher`s engaged influenced the studied issues. } \\
\text { - Constraints associated with the need to ethics } \\
\text { approval for research related to people. } \\
\text { - Difficulties in assessing customer`s purchasing } \\
\text { motivations and judging value in advance and their } \\
\text { risks perceptions. }\end{array}$ \\
\hline Nature of Demand & $\begin{array}{l}\text { Level of demand: } \\
\text { - Demand, sometimes exceed } \\
\text { capacities } \\
\text { Degree of fluctuation: } \\
\text { - Variable } \\
\text { (for example, in the case of } \\
\text { Jordan : the majority of } \\
\text { customers prefer the pre-paid } \\
\text { cards rather than the annual } \\
\text { subscription contracts) }\end{array}$ & $\begin{array}{l}\text { - Different theories and perceptions related to demand } \\
\text { (economic, marketing and social) to be considered } \\
\text { in evaluating process. } \\
\text { - Different factors to be taken into account (the role } \\
\text { of prices techniques, promotion, training, etc.) for } \\
\text { evaluating firm`s efforts in managing demand }\end{array}$ \\
\hline Service Package & $\begin{array}{l}\text { Number of services and goods: } \\
\text { - Package of multiple } \\
\text { telecommunication services } \\
\text { and multiple complementary } \\
\text { goods. }\end{array}$ & $\begin{array}{l}\text { - More difficulties in measuring customer satisfaction } \\
\text { because of the multi-dimensional component that } \\
\text { affect customer evaluating (network coverage, } \\
\text { firm's employees' performance, time, etc.). }\end{array}$ \\
\hline
\end{tabular}




\begin{tabular}{|c|c|c|}
\hline Service Package & $\begin{array}{l}\text { Degree of equipment base: } \\
\text { - High (infrastructure, complex } \\
\text { telecommunication software, } \\
\text { etc.) } \\
\text { (may not seen clearly by the } \\
\text { consumer) } \\
\text { Degree of durability: } \\
\text { - Low } \\
\text { (Regarding the rapid telecom - } \\
\text { technology, telecom short life } \\
\text { cycle services and the rapid } \\
\text { developments related to the } \\
\text { complementary tangible goods.) }\end{array}$ & $\begin{array}{l}\text { - Difficulties in assessing customer satisfaction with } \\
\text { specific pure service. } \\
\text { - Difficult to investigate the factors that affect } \\
\text { customer's preferences developments because of the } \\
\text { dynamic evolving industry. } \\
\text { - Difficult to assess customer`s value perception as it } \\
\text { is influenced by many social, financial, } \\
\text { psychological and cultural factors. }\end{array}$ \\
\hline Delivery Method & $\begin{array}{l}\text { Availability of service: } \\
\text { - Multiple sites } \\
\text { Nature of delivery: } \\
\text { - Continuous } \\
\text { Type of consumption: } \\
\text { - Collectively } \\
\text { (within a wide global networks) }\end{array}$ & $\begin{array}{l}\text { - Ambiguity or inability in identifying points of } \\
\text { strength and points of weakness of the applied } \\
\text { delivery methods because of the complexity and } \\
\text { multiplicity of roles. }\end{array}$ \\
\hline
\end{tabular}

*Adapted from: Kurtz and Clow (1998)

\section{TRIANGULATION TECHNIQUES AND TELECOMMUNICATION SERVICES RESEARCH COMPLEXITIES}

Triangulation offers a wide range of methodological strategies and techniques all aimed at enabling researchers to increase the validity, credibility and generalization of research results so as to allow circumventing the inaccuracies and eliminating of potential bias. Researchers within high tech-services - as the case of Jordanian telecommunication services industry - are faced by critical constrains influence negatively the acceptance of research results.

The predominant characteristics of provided services, the structure of the telecommunication industry, the TSPs-Customer relationship, the nature of demand and delivery methods all required a sophisticated methodological perspective dealing effectively 
with the researcher's anticipated challenges and difficulties.

Different methodological strategies were suggested by Mason (2006) based on linking the social research impediments with its appropriate multi-methods alternatives:

- $\quad$ Mixing methods for a close-up illustration of a bigger picture, or for background.

- $\quad$ Mixing methods with a parallel logic. (Research experiences and unrelated to ask and answer differently conceived or separate questions).

- $\quad$ Mixing methods to ask questions about connecting parts, segments or layers of a social whole.

- $\quad$ Mixing methods to achieve accurate measurement through triangulation.

- A multi-dimensional triangulation. (Mixing methods to ask distinctive but intersecting questions).

The work developed by Mason (2006, pp. 4-10) is considered as a broad strategic framework for a pluralist researching approach, based on classifying the multi-methodological alternatives within five strategies. The five general strategies reflect the source from which various techniques of triangulation are drawn from.

"Mixing methods for a close-up illustration of a bigger picture", as strategic research approach that introduces many techniques to enable researchers achieve a comprehensive an in-depth understanding for the phenomenon as Mason (2006) explained. For example, to explore the adopting of the strategic philosophy "customer orientation perspective" within Jordanian telecommunication provision, triangulation provides a "more close-up view" for the phenomenon background through mixing different methods. On one hand a single or multi-case study as a qualitative technique enables "capturing of reality and detail by studying a phenomenon in its natural context" (Cavaye, 1996), on the other hand statistical or financial quantitative data complement and enrich the overall image.

Some research comprises different unrelated aspects which require searching simultaneously within differently parallel lines (mason, 2006). For example, “to evaluate the rapidly evolving of customer preferences related to short life cycle provided services within privatization and open market polices in the Jordanian telecommunication industry“. Evaluating process includes two main domains:

- $\quad$ Consumer behavioural - social, psychological - and service marketing background aspects. 
- Legislation and laws related telecommunications (pricing policies, international alliances, confidentiality of customers' data, infrastructure and its related laws) aspects.

Through two parallel areas, theory triangulation and researcher triangulation techniques allow consumer behavioural researchers and researchers with expertise in telecommunications legislation contribute the overall findings validity. A wide survey -as quantitative instrument aims at tracing the different developments of consumer's preferences based on the behavioural related theories.

Furthermore, the holistic dimension is to be considered for achieving a clear understanding of the legislation environment. "Holistic outlook in any research is to gain a comprehensive and complete picture of the whole context in which the phenomena of interest occur. It is an attempt to describe and understand as much as possible about the whole situation of interest" (Gilmore and Carson, 1996, p. 23). Semi-structured interviews with senior managers, experts and executive directors in the main services telecommunication providers (TSPs) who present the higher involvement and participation in their organizations, will allow "greater degree of sense-making, and richer descriptive and analytical possibilities for the data“ as Rouse and Daellenbach (1999, p. 490) stated. The implementation of measuring customer satisfaction within telecommunication services may represent a prominent practical benefit of applying the triangulation techniques. By matching telecommunication services complexities to the most appropriate research methodologies, triangulation aims at supporting the findings or conclusions of research "much more convincing and accurate" (Yin, 1994; Miles and Huberman, 1994) in Alam (2005).

Assessing customer satisfaction within telecommunication provision in Jordan requires identifying the critical elements that lead to the overall satisfaction. In addition to the behavioural measurements (loyalty and recommendation), service quality, service value, promotion and communication, complaints, delivery and firm staff, all have to be presented in the satisfaction measurement tool.

Even whilst the components of satisfaction measurement tool have been identified, the telecommunication service nature, integration of acts and interactive relationship pose vexing obstacles that seem to face the measuring process itself.

In more detail, many aspects contribute the complexity of telecommunication service customer satisfaction measuring: 
- Unique telecommunication services characteristics.

- Telecommunication service providers (STPs)-customer dynamic and interactive relationship.

- Difficulties in determining factor that influence customer's preferences.

- Ambiguity in identifying points of strength and points of weakness of the applied delivery methods because of the complexity and multiplicity of roles.

- Difficulties in evaluating customer perceptions risk and service quality related to inseparability.

- Customer's judgment on the quality of provided services is influenced by internal and external circumstances during receiving telecommunication service.

- Difficulties in evaluating the rapidly evolving of customer preferences, needs and tastes, related to the short life cycle services.

Therefore, services are activities (Regan, 1963) that could not be simplified in processing customers and their orders. Services are the behaviour of employees, and the impressions of customers made during the mutual interaction (Martin, 1999). Hence, to gauge customer satisfaction with specific service or to measure the quality of provided service, the researcher has to consider the suitability of the adopted methodological approach.

In line with Mason's (2006) work, the researcher may draw on "mixing methods to achieve accurate measurement through triangulation " as a strategy for measuring customer satisfaction accurately. Within corroborative logic, triangulation techniques enable researchers to diversify data sources, theories and methodologies through a - mutually reinforcing - strategic perspective that can ultimately underpin the accurateness of "identifying the main components of the measurement tool related to telecommunication services customer satisfaction“.

The parallel logic research approach represents research within multi methodological unrelated lines (Mason, 2006). To the contrary, both of the mixing methods with integrative logic research strategy and the multi-dimensional logic research strategy are based on utilizing all research techniques iteratively in order to support research findings validity, credibility and persuasiveness.

Mixing methods with integrative logic manages sort of "questions about connecting parts, segments or layers of a social whole “. Whereas, the multi-dimensional logic strategy is considered as the methodological preferred approach where "intersecting questions and variety of views" which require a multi-methodological triangulation techniques too (mason, 2006). For example, to assess "the impact of customer`s opinions and convictions about the health 
influences of electromagnetic fields on mobile penetration rate within telecommunication services provision in Jordan ", the evaluating process includes three main connected domains:

- Consumer behavioural (social and psychological) and service marketing background aspects.

- Medical background related the effects of "electromagnetic field" on human beings.

- Telecommunication technology (telecom infrastructure and telecom legislation background) aspects.

It is evident that the different aspects: consumer behavioural, medical background and telecommunication technology are represented in the research query as interconnected and interactive aspects. Experienced researchers with different backgrounds (behavioural, medical and telecom infrastructure) will work iteratively as teams.

Different data sources, methods and theories could be developed by specialist research teams according to their aspect's requirements. High degrees of coordination are recommended in all research stages.

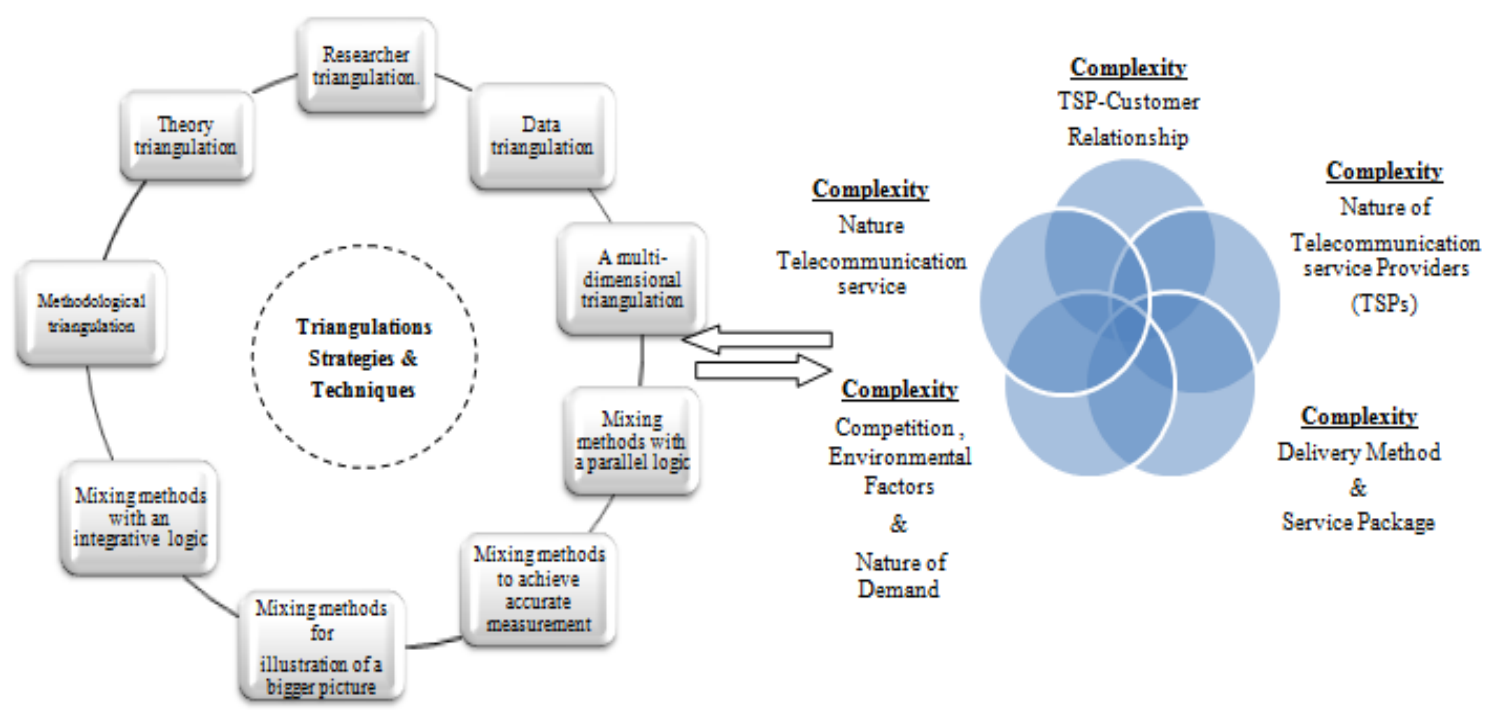

Figure2: Telecommunication Services Research Complexities and Triangulation`s

\section{Techniques}

Finally, Gilmore and Carson (1996) emphasized suitability of the interpretative analysis of data and the experiential knowledge and understanding of the researcher in the context of services. Focusing on both: "Interpretative analysis of data" and "descriptive data" appropriateness (Gilmore and Carson, 1996) in providing “depth and detail” about "events, situations and interactions between people" (Patton, 1980). 
The interpretive approach enables researchers to focus on understanding what is happening in a given phenomena context and interpretation of data (Carson, et al., 2001). Similarly, it allows a clearer understanding of complex situations involving human and organizational behaviour (Remenyi, et al., 1998). In this regard, evaluating services where people interaction and integration of acts, it is suggested to " be done not only on organizations but also in organizations“ (Rouse and Daellnbach, 1999).

Furthermore, an interpretive methodology is important for gathering and explaining attitudes and opinions of people. It allows achieving a substantial meaning and understanding of the how and why questions (Carson, et al., 2001). Interpretive methodology enables deep comprehension of the validity of specific marketing capabilities which could be perceived as a source of competitive advantage within Jordanian telecommunication services provision and how these capabilities could be combined and managed.

\section{CONCLUSIONS}

Triangulation as a multi-methodological approach, offers various techniques for supporting research findings focusing on increasing the validity by varying in data, researchers, theories, methodologies or environments.

In line with related literature, researcher may face difficulties and constraints in evaluating within tech-based services markets.

Because of the unique attributes of telecommunication services where interaction between people, overlapping in roles and integration of acts are expected, triangulation is considered as an appropriate research technique in such stiff competition and dynamic markets. Triangulation - through all research stages- enables researchers to expand the methodological alternatives horizontally and vertically aiming at increasing the validity and creditability of evaluation findings. 


\section{REFERENCES}

Ader, H. J., Mellenbergh, G.J. and Hand, D.J. (2008). Methodological quality. Advising on Research Methods: A consultant's companion. Johannes van Kessel Publishing.

Al-Busaidi, Z. (2008). Qualitative Research and its Uses in Health Care. Sultan Qaboos University Medical Journal, 8 (1), 11-19.

Afridi, F. K. (2009). Extended Services Marketing Mix and Emergence of Additional Marketing Ps. The Journal of Managerial sciences, 3 (1), 137-143.

Ahn, J.-H., Cha, K., Jun, D. and Park, M. (2004). Bridging telecommunications service: its concept and related management strategy. Telecommunications Policy, 28 (9-10), 733-750.

Alam, I. (2005). Fieldwork and data collection in qualitative marketing research. Qualitative Market Research: An International Journal, 8 (1)97-112.

Altrichter, H., Feldman, A., Posch, P. and Somekh, B. (2008). Teachers investigate their work; An introduction to action research across the professions. 2nd edition. Routledge.

Ammenwerth, E., Iller, C. and Mansmann, U. (2003). Can evaluation studies benefit from triangulation? A case study. International Journal of Medical Informatics. 70 (2), 237-248.

Boaz, A. and Sidford, A. (2005). Reviewing Existing Research. In: Gilbert, Nigel, (ed.) From postgraduate to social scientist : a guide to key skills. London, U.K. : SAGE Publications. pp. 7-24. ISBN 9780761944607.

Bateson, J. E. G. (1977). Do we need services marketing? Marketing Consumer Services: New Insights, Marketing Science Institute Report, December, 77-115.

Bateson, J. E. G. (1979). Why We Need Service Marketing. in Ferrell, O. C., Brown, S. W. and Lamb, C. W. (Eds), Conceptual and Theoretical Developments in Marketing. American Marketing Association, Chicago, IL, 131-46.

Bettany-Saltikov, J. (2012). How to do a systematic literature review in nursing. Berkshire: Open University Press.

Berry, L. L. (1980). Service Marketing Is Different. Business, 30 (May-June), 24-29.

Bharadwaj, S. G., Varadarajan, P. R. and Fahy, J. (1993) Sustainable competitive advantage in service industries: a conceptual model and research propositions. Journal of Marketing, 57 (4), 83-99.

Bogdan, R. C. and Biklen, S. K. (2006). Qualitative research in education: An introduction to theory and methods. 4th edn. Allyn and Bacon.

Booms, B. and Bitner, M. (1981). Marketing Strategies and Organisation Structures for Services Firms, in Donnelly, J. and George, W. (1981) 'marketing of services, special educators' Conference Proceeding, Chicago, American Marketing Association, 46-51.

Bryman, A. (n.d.). Triangulation and Measurement", [Online] Available at: http://www.referenceworld.com/sage/socialscience/triangulation.pdf

Bryman, A., Becker, S. and Sempik, J. (2008). Qualitative and Mixed Methods Research: A View from Social Policy. Int. J. Social Research Methodology, 11 (4), 261-276.

Campbell, D. T. and Fiske, D. W. (1959). Convergent and discriminant validation by the multitrait-multimethod matrix. Psychological Bulletin, 56 (2), 81-105.

Carson, D., Gilmore, A., Perry, C. And Gronhaug, K. (2001). Qualitative Marketing Research, London: SAGE.

Cavaye, A. L. M. (1996). Case study research: a multifaceted research approach for IS. Information System Journal, 6 (3), 227-242.

Denzin, N. K. (1978). The Research Act: A Theoretical Introduction to Sociological Methods. 2nd edn. New York: McGraw Hill.

Erzberger, C. and Prein, G. (1997). Triangulation: Validity and empirically-based hypothesis construction. Quality and Quantity, 31(2) 141-154.

Fitzsimmons, J. A. and Fitzsimmons, M. J. (2006). Services Management, Operations Strategy, Information Technology. 5th edn. New York: McGraw-Hill. 
Gibson, C. B. (2017). Elaboration, Generalization, Triangulation, and Interpretation: On Enhancing the Value of Mixed Method Research. Organizational Research Methods, 20 (2), 193-223.

Gilmore, A. and Carson, D. (1996). Integrative qualitative methods in services context. Marketing Intelligence and Planning, 14 (6), 21-26.

Goncalves, K. P. (1998). Service Marketing - A strategic Approach. New Jersey: Prentice Hall.

Guion, L. A. (2002). Triangulation Establishing the Validity of Qualitative Studies. University of Florida. Publication.

Holtzhausen, S. (2001). Triangulation as a powerful tool to strengthen the qualitative research design: The Resource-based Learning Career Preparation Programme (RBLCPP) as a case study. Higher Education Close Up Conference 2. 16-18 July 2001. Lancaster University.

Johari, L. M., Singh, J.D., Sinha, P.K., Sehgal, A., Ramdas, D., Agarwal, M.L. (2004). Marketing of Services. Indira Gandhi National Open University. School of Management Studies.

Kern, F. G. (2016). The Trials and Tribulations of Applied Triangulation: Weighing Different Data Sources. Journal of Mixed Methods Research. ISSN 1558-6898.

Kitchenham, B. (2004). Procedures for performing systematic review. Available at: http://www.idi.ntnu.no/emnee/empsc/papers/ kitchenham_2004.

Kurtz, L. D. and Clow, K. E. (1998). Service Marketing. USA: John Wiley and Sons.

Lovelock, C., Vandermerwe, S. and Lewis, B. (1999). Services Marketing: European Perspective. New York: Prentice Hall Inc.

Martin, C. L. (1999). The history, evolution and principles of services marketing: poised for the new millennium. Marketing Intelligence and Planning, 17 (7), 324-328.

Mason, J. (2006). Six strategies for mixing methods and linking data in social science research. ESRC National Centre for Research Methods. University of Manchester.

Mathison, S. (1988). Why Triangulate?. Educational Researcher, 17 (2),13-17.

McCarthy, J. (1964). Basic Marketing: A Managerial Approach. 2nd edn. Richard D. Irwin, Inc.

Miles, M. B. and Huberman, A. M. (1994). Qualitative Data Analysis. Thousand Oaks: Sage.

Olsen, W. (2004). Triangulation in Social Research: Qualitative and Quantitative Methods Can Really Be Mixed. Final version. Forthcoming as a chapter in Developing in Sociology, 2004, ed. M. Holborn, Ormskirk: Causeway Press.

Palmer, A. (2001). Principles of services marketing. England: McGraw-Hill Publishing Company.

Patton, M. Q. (1980). Qualitative Evaluation Methods. Sage, Beverly Hills, CA.

Perlesz, A. and Lindsay, J. (2003). Methodological triangulation in researching families: making sense of dissonant data. Int. J. Social Research Methodology, 6 (1), 25-40.

Regan, W. J. (1963). The Service Revolution. Journal of Marketing, 27 ( 3), 57-62.

Remenyi, D., Williams, B., Money, R. and Swartz, E. (1998). Doing Research in Business and Management: An Introduction to Process and Method. London: Sage.

Rouse, M. J. and Daellenbach, U. S. (1999). Research notes and Communications rethinking research methods for the resource-based perspective: isolating source of competitive advantage. Strategic Management Journal, 20 (5), 487-494.

Sambunjak, D., and Puljak, L. (2010). Cochrane systematic review as a PhD thesis: an alternative with numerous advantages. Biochemia Medica, 20 (3), 319-326.

Shostack, G. L. (1977). Breaking Free From Product Marketing. Journal of Marketing, 41 (2), 73-80.

Smith, M. L., and Kleine, P. L. (1986). Qualitative research and evaluation: Triangulation and multimethods reconsidered. In D. D. Williams (Ed.), Naturalistic evaluation (New Directions for Program Evaluation, No. 30). San Francisco: Jossey-Bass.

Turner, S., F., Cardinal, L.B. and Burton, R.M. (2017). Research Design for Mixed Methods: A Triangulationbased Framework and Roadmap. Organizational Research Methods, 20 (2), 243-267. 
Van Manen, M. (1990). Researching lived Experience: Human Science for an Action Sensitivity Pedagogy. London: Althouse Press.

Wright, L. T. (1996). Exploring the in-depth interview as a qualitative research technique with American and Japanese firms. Marketing Intelligence \& Planning, 14 (6), 59-64.

Yin, R. K. (1994). Case Study Research: Design and Methods. 2nd edn. Newbury Park, CA: Sage.

Zeithaml, V. A. and Bitner, M. J. (1996). Services Marketing. USA: McGraw-Hill.

Zeithaml, V. A., Parasuraman, A. and Berry, L. L. (1985). Problems and Strategies in Services Marketing. Journal of Marketing, 49 (2), 33-46. 